stidspunkt i drabssager; blodtypebestemmelser og DNA-teknologi; og gerningsmandsprofilering.

Anders Draby Sorensen

\title{
Italiensk frihedsontologi i Schellings ånd
}

Luigi Pareyson:

Person og eksistens (oversat fra italiensk og med efterskrift af Jens $V$. O. Nielsen), Aarbus Universitetsforlag, 2011 , 384 sider, $349,95 \mathrm{kr}$.

Den italienske eksistensfilosof og hermeneutiker Luigi Pareyson (1918-1991) regnes i sit hjemland for én af det 20. århundredes væsentligste filosoffer. Pareyson var lærer for så prominente tænkere som bl.a. Umberto Eco og Gianni Vattimo, og studerede selv under bl.a. selveste Karl Jaspers i Heidelberg. Det gælder i øvrigt - til de flestes formodentlige overraskelse - at Pareyson faktisk gav sit oprindelige bud på en moderne, filosofisk hermeneutik tidligere endnu end de to tænkere, der ellers opfattes som fortolkningsfilosofiens sædvanlige faderfigurer; nemlig Hans-Georg Gadamer og Paul Ricoeur.

På dansk forelå indtil for nylig oversættelser af en mindre del af Pareysons Æstetik - Formskabelsens teori (1954) (der vel at mærke omtales rosende i Gadamers Wabrheit und Methode) såvel som af hans temmelig komprimerede men også uhyre læseværdige afskedsforelæsning fra 1988, Fribedens filosofi, der tilmed er forsynet med et fint forord fra danske Søren Gosvig Olesens pen. Samme Gosvig arbejder efter sigende på en oversættelse af det omfattende og sene hovedværk, Ontologia della libertà, der udkom posthumt i 1995, og som en syg og følgelig stærkt svækket Pareyson møjsommeligt arbejdede på i de sidste par årtier af sit liv.

Selvom Pareysons sene mellemværende med en Schelling-inspireret frihedsontologi efter alt at dømme udgør forfatterskabets filosofiske kulmination, er det afgjort tiden og koncentrationen værd 
foreløbig at kaste sig over den nyligt oversætte moppedreng, Eksistens og Person fra 1950 (sidenhen modificeret i udgaver fra 1960, 1966 og 1985), der således har status som Pareysons tidlige(re) hovedværk. Værket er oversat til et fint læseligt (om end en smule arkaisk) dansk og desuden forsynet med et hele 129 sider langt efterskrift af Jens Viggo Olavi Nielsen, der af samme grund(e) må formodes at have investeret en hel del arbejde i denne udgivelse. Og hatten af herfor, selvfølgelig.

Eksistens og Person åbner (efter en "Introduktion" fra værkets fjerdeudgave) med en tekst om den fremtidige filosoferens "To muligheder - [nemlig] Kierkegaard og Feuerbach" - eller med andre ord: den moderne filosofis uomgængelige »Enten-Eller« mellem en (religiøst orienteret) eksistentialisme og (ateistisk orienteret) materialisme. Det er i denne sammenhæng Pareysons ikke længere fuldstændig uproblematiske præmis (jf. nyere læsninger af bl.a. Pippin, Gabriel, Houlgate, Žižek m.fl.), at »hegelianismens [i.e. den rationalistiske metafysiks] opløsning « og sammenbrud implicerer en genovervejelse »om muligheden af at filosofere« (s. 87), der i sidste instans nødvendiggør et sådant valg.

Af forskellige mere eller mindre overbevisende grunde mener Pareyson, at vi har filosofiske grunde til at følge i eksistenstænkningens - snarere end materialismens - fodspor. For det forste leverer eksistentialismen den mest konsekvente kritik af det »fornuftens overmod«, der kendetegnerne »nutidens krise« (ibid.). For det andet rummer eksistentialismen en reel forståelse for den virkelige trussel fra (eller mulighed for) såvel ateistisk materialisme som nihilisme, der ikke - så at sige - bliver gengældt. Eller som Pareyson udtrykker det: »Skønt Kierkegaard bevarer den nærværende mulighed af en position som Feuerbachs, så kontemplerer Feuerbach omvendt ikke muligheden af en Kierkegaard, hvilket medfører, at alternativets to muligheder ikke er ligeværdige« (s. 13). Disse afgørende argumenter fremstår for denne anmelder på flere måder som tvivlsomme. Eksempelvis kan, som jeg læser det, »en Kierkegaard« udelukkende tolerere muligheden for en position som Feuerbachs ved akkurat at udelukke, at en objektiv sandhed i realiteten skulle kunne være sandheden for et eksisterende subjekt. Eller anderledes udtrykt: Kierkegaard gør materialismen meningsfuld på sine egne (eksisten- 
tielle) præmisser, akkurat som Feuerbach (udelukkende!) ville kunne give mening til en Kierkegaardsk religiøsitet ved at "oversætte" den til noget i retning af en objektivt (altså historisk-politisk) indlejret projektion. For det tredje er strukturen i Pareysons argument sært magen til John Stuart Mills heller ikke just uangribelige begrundelse i sine Utilitarianism-essays for, at Sokrates skulle have mere ret end den uuddannede mht. kvaliteten af forskellige præferencetyper, fordi han - vel at mærke i modsætning til den udannede - kender til såvel intellektuelle som mere sanselige lyster. Jeg er aldrig blevet overbevist af Mills argument, og bliver det heller ikke for indeværende af Pareysons "variation".

Styrken i Eksistens og person ligger langt snarere i, hvad Pareyson så stiller op med det valg til fordel for en mere eksistensorienteret tænkning, han nu engang har truffet. Det viser sig tilmed i løbet af de 12 essays (foruden en "Introduktion" henholdsvis en "Konklusion”), som værkets tre dele indeholder, at Pareyson ønsker at fremskrive et begreb om "personen «, der ikke kun trækker veksler på eksistentialismens subjektforståelse, men også ser sig selv som en »berigtigelse« af denne (s. 229). Det er i denne sammenhæng Pareysons anke, at eksistensfilosofien, når alt kommer til alt, ikke har formået at overskride hegelianismens forfejlede filosofiforståelse, eftersom den i sin iscenesættelse (hos bl.a. Kierkegaard) af eksistensens subjektive sandhed overfor tænkningens logiske objektivitet $i$ vid udstrækning er forblevet indenfor en uacceptabel og falsk dikotomi mellem væren som tænkning (Hegel) og væren som eksistens (Kierkegaard).

Pareysons videreudvikling - og overskridelse - af eksistenstænkningen, der skal rette op på disse mangler, og som han henviser til som en art »ontologisk personalisme«, trækker på sin side eksplicitte veksler på en anden af den tyske idealismes hovedpersoner, nemlig Friedrich Wilhelm Joseph Schelling. I flere af sine essays udvikler Pareyson således et Schelling-inspireret personbegreb, der især handler om, hvorledes den menneskelige friheds udspændthed - eller »ambivalens« - mellem aktivitet og passivitet, håb og angst samt godt og ondt »har en objektiv årsag $i$ virkelighedens ambivalens«. Denne ontologiske Aufhebung af eksistensfilosofien, der samtidig er en art venden tilbage til proto-eksistenstænkeren Schelling, 
er således ikke først at fremmest at forstå som en »fænomenologi om den menneskelige frihed, men [...] en ontologi for den oprindelige frihed, der udgør virkelighedens og eksistensens begyndelse« (s. 31). Det kan ikke lade sig gøre at yde retfærdighed mod Pareysons komplekse argumenter for sin personalisme hér, men Pareysons synspunkter er ganske givet ikke blevet mindre aktuelle, efterhånden som flere filosoffer (bl.a. Hutter, Hogrebe og allerede nævnte Gabriel og Žižek) i de senere år synes at have genoptaget Schelling.

Jens Viggo Olavi Nielsens omfattende, grundige og samvittighedsfulde "Efterord" er helt afgjort også værd at læse. Det er desuden bemærkelsesværdigt, hvordan Olavi Nielsen her lægger sig grundigt ud med den anden af Danmarks bedst kendte Pareysonfortolkere, nemlig Søren Gosvig Olesen.

Kresten Lundsgaard-Leth

\title{
Tilbage til fremtiden - et pragmatisk værks mystiske genkomst
}

\author{
Jobn Dewey: \\ Unmodern Philosophy and Modern Philosophy, \\ Southern Illinois University Press, \\ 2012, 352 sider, 60,00 USD.
}

Da han var i begyndelsen af firserne, midt under 2. verdenskrig, påbegyndte den nok største af de klassiske amerikanske pragmatister, John Dewey (1859-1952), et værk som skulle opsummere hans livsværk og udgøre "en 'social' fortolkning af filosoffers, hvis ikke filosofiens, historie" - en filosofiens kulturhistorie. Men da manuskriptet næsten var færdigt slog skæbnen til og i noget som minder om en scene fra en ikke helt troværdig film glemte Dewey det i en taxa hvorefter han aldrig så det igen og opgav at begynde forfra. Siden hans død har Dewey-interesserede forskere naturligt nok spekuleret over hvad indholdet af denne bog ville have været og om den ville have rummet nye, interessante tanker. Men samtidig har de også været bevidste om at det selvfølgelig var en håbløs og nytteløs 